\title{
The effect of some seasonal conditions on oestrus occurrence in cows
}

\author{
BÜLENT BÜLBÜL ${ }^{1}$ and MEHMET BOZKURT ATAMAN²
}

\begin{abstract}
'Department of Artificial Insemination and Biotechnology, Bahri Dağdaş International Agricultural Research Institute, Konya, Turkey, ${ }^{2}$ Department of Reproduction and Artificial Insemination, Faculty of Veterinary Medicine, University of Selçuk, Konya, Turkey
\end{abstract}

\section{Abstract}

In this study, the effect of climatic conditions on oestrus occurrence was investigated by using 9972 oestrus records of cows recorded between 1995 and 2003. A distinct seasonal variation in the oestrus occurrence was determined. Oestrus occurrence observed in January, March, November and December was less than that in June and September $(P<0.05)$. Annual distribution of the oestrus occurrence was positively correlated with environment temperature and insulation duration, but it was negatively correlated with rainfall $(P<0.01)$. However, there was no relationship between oestrus occurrence and relative humidity. In addition to these, there was a slight decrease in the oestrus response when the temperature-humidity index (THI) was above 72; nevertheless, this decrease was not significant $(P>0.05)$. The data presented in this study demonstrated that the increase in the environmental temperature up to $23^{\circ} \mathrm{C}$ did not cause a suppressive effect on the ovarian activity. In conclusion, annual distribution of the oestrus occurrence is positively correlated with environment temperature and insulation duration whereas it is negatively correlated with rainfall in Holstein cows, in this study.

Keywords: cattle, climatic conditions, oestrus response

\section{Zusammenfassung}

\section{Einfluss der Jahreszeiten auf die Brunst bei Kühen}

An Hand von 9927 Östrusdaten von Holsteinkühen aus den Jahren 1995 bis 2003 wurde der jahreszeitliche klimatische Einfluss auf das Brunstgeschehen bei Kühen untersucht. Grund war die Beobachtung einer saisonalen Veränderung des Östrusauftretens. So wurde ein geringeres Brunstauftreten in den Monaten Januar, März, November und Dezember gegenüber den Monaten Juni und September beobachtet. Die Datenanalyse ergab, dass signifikant das jahreszeitliche Östrusauftreten positiv mit der Umgebungstemperatur und der Sonnenscheindauer aber negativ mit der Niederschlagsmenge korreliert war. Keine Zusammenhänge fanden sich zwischen der relativen Luftfeuchtigkeit und dem Östrusgeschehen. Tendenziell wurde eine geringe Abnahme der Östren nachgewiesen, wenn der Wert des Temperatur-Feuchtigkeits-Indexes (THI) über 72 lag. Die Ergebnisse dieser Studie zeigen, dass Umgebungstemperaturen bis zu $23^{\circ} \mathrm{C}$ die Ovarienaktivität nicht negativ beeinflussen. Zusammenfassend wird geschlussfolgert, dass bei dem vorliegenden Tiermaterial ein jahreszeitliches Östrusverhalten positiv mit 
der Umwelttemperatur sowie der Sonnenscheindauer, jedoch negativ mit der Niederschlagsmenge korreliert ist.

Schlüsselwörter: Kuh, Jahreszeit, Brunst

\section{Introduction}

Cows are polioestric and have cyclic activity throughout the year. However, seasonal variations are effective on cyclic activity as well as on reproduction in cows and heifers (MCNATTY et al. 1984, PENNINGTON et al. 1985, BORELL 2000, WHITE et al. 2002). Environment temperature has an important role on reproductive performance (WILLARD et al. 2003). High environment temperature and relative humidity influence endocrine activity and reduce reproductive efficiency (RYAN et al. 1992, GREVE et al. 1996, DEMIRCI 2002, DERENSIS et al. 2002, SARTORI et al. 2002, SÖNMEZ et al. 2005).

The detrimental effects of heat stress are the suppressed intensity of oestrus, a reduced magnitude of the preovulatory luteinizing hormone (LH) surge, decreased secretion of luteal progesterone, altered ovarian follicular development, decreased embryo development and lower fertility (KANITZ et al. 2001, AL-KATANANI et al. 2002, MANTEUFFEL 2002, WILLARD et al. 2003). Negative energy balance due to heat stress leads to reduced LH secretion and anovulation in dairy cows. Therefore, low oestradiol secretion from the dominant follicle (DOBSON and SMITH 2000) causes poor expression of oestrus with a reduction of oestrus detection rate and fertility (DE LA SOTA et al. 1998). Hyperthermia caused by heat stress decreases conception rate by increasing embryonic mortality (DE LA SOTA et al. 1998). Progesterone levels in luteal phase of oestrus in winter are higher than those in summer (ALNIMER et al. 2002). Motor activity and other signs of oestrus are reduced and the incidence of anoestrus and silent ovulation are increased by heat stress in summer (HANSEN and ARÉCHIGA 1999, DE RENSIS and SCARAMUZZI 2003).

One of the most common ways of measuring the severity of heat stress in cattle is the temperature-humidity index (THI) (ARMSTRONG 1994, CARTMILL et al. 2001). THI is computed from the environment temperature and relative humidity measurements using a formula described before (ALNIMER et al. 2002). It is agreed that a THI value above 72 is stressful to dairy cows (SÖNMEZ et al. 2005).

In addition to the environment temperature and relative humidity, reproductive performance is affected by wind and photoperiod (GWAZDAUSKAS 1985, ORIHUELA 2000).

Because of the literature, we hypothesized that there would be correlation between oestrus response and some climatic conditions (environment temperature, relative humidity, insulation duration and rainfall), and the effects of these climatic conditions on oestrus occurrence were evaluated in cows, in this study.

\section{Material and methods}

This study was conducted in Şile, Istanbul, Turkey at the location of $41^{\circ} 14^{\prime}$ parallel and $29^{\circ} 36^{\prime}$ longitude. The oestrus records of cows were taken by veterinary surgeons in Şile Country Agriculture Directorship between 1995 and 2003. The records in 2001, 2002 and 2003 were taken by researchers on their own. A total of 9972 oestrus records of 
reproductively normal (no purulent discharge during oestrus examination, minimum 50 days post partum), lactating Holstein dairy cows and heifers were evaluated cumulatively without splitting into successive years. The animals were housed indoors, milked twice a day, fed with a total mixed ration three times a day to meet the requirements of lactating cows, and had access to fresh water ad libitum.

Oestrus response was considered as the ratio of oestrus records in a month to the oestrus records totally in a whole year. All data obtained as years were combined and evaluated monthly in a whole year to realize the average data for months in a year. First, oestrus of each cow was followed by farmers according to the overt signs of oestrus (standing heat, vaginal discharge, red and swollen vulva, restlessness and reduced milk production) by 30 min observations twice a day. Second, these signs were confirmed by a veterinarian by visual observation and rectal palpation (a fluctuant dominant follicle and uterine tonus) in 2-5 h after first oestrus detection. Onset of the observations for oestrus was after post partum 45 days (voluntary waiting period). Each cows oestrus data was used only once for a year; that is, if a cows oestrus data was used once, it has not been used for another time in the same year.

Insulation duration (sunny hours of day) was considered as a period of time of daylight in a day. The information on monthly variation in environment temperature, relative humidity, rainfall and insulation duration were obtained from the local meteorological laboratory. The data were measured for three times in a day and the daily and monthly average values were calculated by local meteorological laboratory. Mean THI was calculated using the formula reported by ALNIMER et al. (2002):

$$
T H I=\left(32+1.8 \cdot{ }^{\circ} \mathrm{C}\right)-\left(0.55-0.55 \frac{\text { Relative Humidity }}{100}\right) \cdot\left[\left(32+1.8 \cdot{ }^{\circ} \mathrm{C}\right)-58\right]
$$

Correlation analysis was performed using the SPSS/PC (SPSS Inc., 10.0 for Windows) computer program to investigate the relationship between meteorological parameters and oestrus. The variation analysis method (one way, ANOVA) was used to evaluate seasonal differences for oestrus rate using the MINITAB (Minitab Inc., Release 12.1) computer program.

\section{Results}

Data of oestrus response (\%), environment temperature $\left({ }^{\circ} \mathrm{C}\right)$, relative humidity $(\%), \mathrm{THI}$ (units), insulation duration $(\mathrm{h})$ and rainfall $(\mathrm{mm})$ were summarized in Table 1.

An important seasonal variation in the oestrus occurrence was determined. Oestrus response was the lowest in December (5.5\%) and the highest in June (10.3\%). In summer months, oestrus occurrence was more than those in winter months. Oestrus occurrence in January, March, November and December was less than those in June and September $(P<0.05)$. In addition, oestrus determined in April, May, June, July, August, September and October was more than those in January and December.

Annual distribution of the oestrus occurrence was positively correlated with environment temperature, $\mathrm{THI}$ and insulation duration, but negatively correlated with rainfall $(P<0.01)$. THI was higher than 72 in July and August. There was a decrease in the oestrus occurrence with the increase of environment temperature over $20.5^{\circ} \mathrm{C}$ (July 
$22.4^{\circ} \mathrm{C}$ and August $23.1^{\circ} \mathrm{C}$ ) and THI over 72 (July 72.2 and August 73.6). However, this decrease was not statistically significant. Insulation duration was higher in summer whereas rainfall was higher in winter. Annual distribution of oestrus occurrence was not correlated with relative humidity.

Table 1

Annual pattern of oestrus response, THI, environment temperature, relative humidity, insulation duration, and rainfall in Şile

Jahreszeitliches Östrusauftreten in \% und Klimadaten sowie Beziehungen zwischen diesen Werten

\begin{tabular}{lcccccr}
\hline Month & $\begin{array}{c}\text { Oestrus } \\
\text { response, } \%\end{array}$ & THl, units & $\begin{array}{c}\text { Environment } \\
\text { temperature, }{ }^{\circ} \mathrm{C}\end{array}$ & $\begin{array}{c}\text { Relative } \\
\text { humidity, } \%\end{array}$ & $\begin{array}{r}\text { Insulation } \\
\text { duration, } \mathrm{h}\end{array}$ & Rainfall, mm \\
\hline January & $6.4^{\mathrm{d}}$ & 42.1 & $5.6 \pm 0.5$ & $84.1 \pm 0.8$ & $2.7 \pm 0.5$ & $78.9 \pm 15.8$ \\
February & $7.9^{\mathrm{bcd}}$ & 41.6 & $5.4 \pm 0.6$ & $80.6 \pm 1.0$ & $4.0 \pm 0.4$ & $79.0 \pm 16.9$ \\
March & $7.5^{\mathrm{cd}}$ & 44.4 & $6.9 \pm 0.9$ & $79.9 \pm 1.7$ & $3.9 \pm 0.4$ & $87.8 \pm 9.4$ \\
April & $8.7^{\mathrm{abc}}$ & 51.2 & $10.7 \pm 0.8$ & $81.3 \pm 1.4$ & $6.6 \pm 1.3$ & $63.4 \pm 9.3$ \\
May & $9.4^{\mathrm{abc}}$ & 60.3 & $15.7 \pm 0.3$ & $83.0 \pm 1.3$ & $6.3 \pm 0.9$ & $22.8 \pm 7.5$ \\
June & $10.3^{\mathrm{a}}$ & 68.9 & $20.5 \pm 0.2$ & $81.9 \pm 1.2$ & $8.5 \pm 0.8$ & $23.3 \pm 6.7$ \\
July & $8.9^{\mathrm{abc}}$ & 72.2 & $22.4 \pm 1.0$ & $83.4 \pm 1.1$ & $7.7 \pm 1.1$ & $41.6 \pm 14.0$ \\
August & $9.1^{\mathrm{abc}}$ & 73.6 & $23.1 \pm 0.3$ & $83.7 \pm 1.5$ & $7.3 \pm 1.0$ & $93.4 \pm 34.9$ \\
September & $9.8^{\mathrm{ab}}$ & 65.2 & $18.5 \pm 0.6$ & $83.6 \pm 1.3$ & $5.9 \pm 0.5$ & $61.0 \pm 10.7$ \\
October & $9.1^{\mathrm{abc}}$ & 60.1 & $15.6 \pm 0.7$ & $83.3 \pm 0.9$ & $4.2 \pm 0.3$ & $123.1 \pm 28.0$ \\
November & $7.4^{\mathrm{cd}}$ & 51.4 & $10.8 \pm 0.5$ & $83.7 \pm 0.9$ & $3.2 \pm 0.3$ & $86.5 \pm 22.7$ \\
December & $5.5^{\mathrm{d}}$ & 45.3 & $7.4 \pm 0.6$ & $82.3 \pm 1.0$ & $1.9 \pm 0.3$ & $115.1 \pm 24.3$ \\
Correlation of oestrus response & & 0.000 & 0.000 & 0.868 & 0.000 & 0.002 \\
p & & 0.434 & 0.433 & -0.17 & 0.392 & -0.307 \\
r & & & & & & 24 \\
\hline
\end{tabular}

$\mathrm{a}, \mathrm{b}, \mathrm{c}, \mathrm{d}$ different letter superscripts denote significant differences within columns $(P<0.05)$ THI: see equation 1 , Data for environment temperature, relative humidity, insulation duration, and rainfall reported as means \pm S.E.M.

\section{Discussion}

Many wild species of Bovidae are seasonal breeders with spring and summer, the most suitable times of the year for calving. During the course of domestication, both dairy and beef cattle were selected against seasonality, facilitating them to ovulate and conceive throughout all the year (JAUNIDEEN and HAFEZ, 1987). However, it is reported that seasonal changes are still affecting reproductive performance in cows and heifers (BADINGA et al. 1985).

In this study, a distinct seasonal variation in the oestrus occurrence was determined. Oestrus occurrence in the January, March, November and December when the environment temperatures were between $5.5^{\circ} \mathrm{C}$ and $7.5^{\circ} \mathrm{C}$ was less than in June $\left(20.5^{\circ} \mathrm{C}\right)$ and September $\left(18.5^{\circ} \mathrm{C}\right)(P<0.05)$. Contrary to this, WHITE et al. (2002) reported that oestrus expression/detection rate was lower in summer (between August and September) when the environment temperature was around at $27.6^{\circ} \mathrm{C}$ than that in winter (DecemberJanuary) when the environment temperature was $5.8^{\circ} \mathrm{C}$. The difference in findings may be because of the difference in environment temperature. In this study, the highest environment temperature was $23.1^{\circ} \mathrm{C}$ in August. HANSEN et al. (2001) reported that environment temperature up to $27^{\circ} \mathrm{C}$ did neither cause hyperthermia nor a negative effect on fertility with the similar findings of the present study. On the other hand, annual distribution of oestrus occurrence was positively correlated with insulation duration in 
this study. The results agree with SALISBURY et al. (1978) who reported that light has a stimulative effect on reproductive performance in cattle and extra light application in winter nights increased oestrus and conception rate. That is, photoperiod has effects on reproductive performance (ORIHUELA 2000). JAINUDEEN and HAFEZ (1987) reported that, beef cows exposed to longer day light during late gestation and calving in the summer and fall resume ovarian cyclicity earlier than those calving in spring. High rates for oestrus response for summer may because of day light. In addition to the effect of daylight, low oestrus response rates for winter may because of pregnancies following artificial inseminations during summer months.

Some researchers reported that high environment temperature influences the endocrine activity and decreases the oestrus expression (LEE 1993, WOLFENSON et al. 1997, ROTH et al. 2001). In this study oestrus occurrence was positively correlated with environment temperature and the increase in the environment temperature up to $23^{\circ} \mathrm{C}$ did not cause a suppressive effect on the ovarian activity. The present results are agree with the findings of O'CONNOR (1993) who reported that the increase in the environment temperature of $23.8^{\circ} \mathrm{C}$ did not cause a suppressive effect on the reproductive performance and oestrus expression. In addition to this, O'CONNOR (1993) emphasized that, environment temperature up to $29.4^{\circ} \mathrm{C}$ had an adverse effect on the reproductive performance and oestrus expression. Even though there was a decrease in the oestrus occurrence with the increase of environment temperature over $20^{\circ} \mathrm{C}$ in the present study, it was not statistically significant.

In spite of the positive correlation of oestrus response with environment temperature, there was a decrease in the oestrus response with the increase of THI over 72 in July and August (72.2 and 73.6, respectively). These findings are similar with SÖNMEZ et al. (2005) who reported that heat stress reduces reproductive performance of cattle when the THI is higher than 72.

Some researchers (DE RENSIS et al. 2002, DE RENSIS and SCARAMUZZI 2003) reported that intensive relative humidity decreases oestrus expression and ovarian activity. In the present study, however, oestrus occurrence was not correlated with the relative humidity.

The present data showed that oestrus response was negatively correlated with rainfall. There is no literature reported about the correlation with rainfall and the annual distribution of oestrus occurrence in cows. In addition, the findings were similar to AKSOY et al. (2002), who studied in Anatolian water buffaloes and reported that oestrus occurrence was negatively correlated with rainfall.

In conclusion, there was a seasonal variation in the oestrus occurrence and it was higher in summer than in winter. In addition to this, annual distribution of the oestrus occurrence was positively correlated with environment temperature and insulation duration whereas it was negatively correlated with rainfall in Holstein cows.

\section{Acknowledgements}

The authors would like to thank Dr. A. H. Aktaş for his statistical assistance; Şükrü Dursun for translation into German; Şile Country Agriculture Directorship in İstanbul Province in Turkey for providing the oestrus records of cows. 


\section{References}

Aksoy M, Kaya A, Uçar M, Lehimcioğlu N, Tekeli T (2002) Effect of seasonal conditions on oestrus occurrence and postpartum period in Anatolian water buffaloes. Dt Tierärztl Wochensch 109, 381-420

Al-Katanani YM, Paula-Lopez FF, Hansen PJ (2002) Effect of season and exposure to heat stress on oocyte competence in Holstein cows. J Dairy Sci 85, 390-6

Alnimer M, De Rosa G, Grasso F, Napolitano F, Bardi A (2002) Effect of climate on the response to three oestrous synchronisation techniques in lactating dairy cows. Anim Reprod Sci 71, 157-68

Armstrong DV (1994) Heat stress interaction with shade and cooling. J Dairy Sci 77, 2044-50

Badinga L, Collier RJ, Thatcher WW, Wilcox CJ (1985) Effects of climatic and management factors on conception rate of dairy cattle in subtropical environment. J Dairy Sci 68, 78-85

Borell von E (2000) Coping strategies during stress. Arch Tierz 43, 441-50 [in German]

Cartmill JA, El-Zarkouny SZ, Hensley BA, Rozell TG, Smith JF, Stevenson JS (2001) An alternative AI breeding protocol for dairy cows exposed to elevated environment temperatures before or after calving or both. J Dairy Sci 84, 799-806

De La Sota RL, Burke JM, Risco CA, Moreira F, Delorenzo MA, Thatcher WW (1998) Evaluation of timed insemination during summer heat stres in lactating dairy cattle. Theriogenology 49, 761-70

Demirci E (2002) Reproduction, Artificial Insemination and Andrology in Domestic Animals, F.Ü. Veteriner Fakültesi Yayın Ünitesi, Elazığ, Turkey [in Turkish]

De Rensis F, Marconi P, Capelli T, Gatti F, Facciolongo F, Franzini S, Scaramuzzi RJ (2002) Fertility in postpartum dairy cows in winter or summer following estrus synchronization and fixed time Al after the induction of an LH surge with GnRH or hCG. Theriogenology 58, 1675-87

De Rensis F, Scaramuzzi RJ (2003) Heat stress and seasonal effects on reproduction in the dairy cow - a review. Theriogenology 60, 1139-51

Dobson H, Smith RF: (2000) What is stress, and how does it affect reproduction. Anim Reprod Sci 60-61, 743-52.

Greve T, Grondahl C, Schmidt M, Hunter RHF, Avery B (1996) Bovine preovulatory follicular temperature: Implications for in vitro production of embryos. Arch Tierz 39 SI, 7-17

Gwazdauskas FC (1985) Effects of climate on reproduction in cattle. J Dairy Sci 68, 1568-78

Hansen PJ, Aréchiga CF. (1999) Strategies for managing reproduction in the heat-stressed dairy cow. J Anim Sci 82 Suppl 2, 36-50

Hansen PJ, Drost M, Rivera RM, Paula-Lopes FF, Al-Katanani YM, Krininger CE, Chase JR CC (2001) Adverse impact of heat stress on embryo production: causes and strategies for mitigation. Theriogenology $55,91-103$

Jainudeen MR, Hafez ESE (1987) Reproductive cycles. In: Hafez ESE (ed) Reproduction in Farm Animals. 5th ed, Lea \& Febiger, Philadelphia, USA

Jordan ER (2003) Effects of heat stress on reproduction. J Dairy Sci E Suppl, E104-E114

Kanitz W, Brüssow KP, Becker F, Torner H, Schneide F, Kubelka M, Tomek EW (2001) Comparative aspects of follicular development, follicular and oocyte maturation and ovulation in cattle and pigs. Arch Tierz $44 \mathrm{SI}, 9-23$

Lee CN (1993) Environmental stress effects on bovine reproduction. Veterinary Clinics of North America Food Animal Practice 9, 263-73

Manteuffel G (2002) Central nervous regulation of the hypothalamic-pituitary-adrenal axis and its impact on fertility, immunity, metabolism and animal welfare - a review. Arch Tierz 45, 575-95

Mcnatty KP, Hudson N, Gibb M, Henderson KM, Lun S, Heath D, Montgomery GW (1984) Seasonal differences in ovarian activity in cows. J Endocrinol 102, 189-98

O'Connor ML (1993) Heat detection and timing of service. Pennsylvania State University Press 402, 1-8

Orihuela A (2000) Some factors effecting the behavioural manifestation of oestrus in cattle: a review. Appl Anim Behav Sci 70, 1-16

Pennington JA, Albright JL, Diekman MA, Callahan CJ (1985) Sexual activity of Holstein cows: seasonal effects. J Dairy Sci 68, 3023-30

Roth Z, Meidan R, Shaham-Albalancy A, Braw-Tal R, Wolfenson D (2001) Delayed effect of heat stress on steroid production in medium-sized and preovulatory bovine follicles. Reproduction 121, 745-51

Ryan DP, Boland MP, Kopel E, Armstrong D, Munyakazi L, Godke RA, Ingraham RH (1992) Evaluating two different evaporative cooling management systems for dairy cows in a hot, dry climate. J Dairy Sci $75,1052-9$ 
Salisbury GW, Vandenmark NL, Lodge JR (1978) Physiology of Reproduction and Artificial Insemination of Cattle. 2nd ed WH Freeman Company, San Francisco, USA

Sartori R, Sartor-Bergfelt R, Mertens SA, Guenther JN, Parrish JJ, Wiltbank MC (2002) Fertilization and early embryonic development in heifers and lactating cows in summer and lactating and dry cows in winter. J Dairy Sci 85, 2803-12

Sönmez M, Demirci E, Türk G, Gür S (2005) Effect of season on some fertility parameters of dairy and beef cows in Elazığ province. Turk J Vet Anim Sci 29, 821-8

White JF, Wettemann RP, Looper ML, Prado TM, Morgan GL (2002) Seasonal effects on estrous behaviour and time of ovulation in nonlactating beef cows. J Anim Sci 80, 3053-9

Willard S, Gandy S, Bowers S, Graves K, Elias A, Whisnant C. (2003) The effects of GnRH administration postinsemination on serum concentrations of progesterone and pregnancy rates in dairy cattle exposed to mild summer heat stres. Theriogenology 59, 1799-810

Wolfenson D, Lew BJ, Thatcher WW, Graber Y, Meidan R (1997) Seasonal and acute heat stress effects on steroid production by dominant follicles in cows. Anim Reprod Sci 47, 9-19

Received 24 July 2008, accepted 14 April 2009.

Corresponding author:

Dr. BÜLENT BÜLBÜL

email: bulbulent@hotmail.com

Department of Artificial Insemination and Biotechnology, Bahri Dağdaş International Agricultural Research Institute, P.K. 125, 42030, Karatay, Konya, Turkey 